\title{
Blunt trauma and acute diseases of the abdomen and chest: Free fluid - what now?
}

\author{
Stumpfes Trauma und akute Erkrankungen des Abdomens und Thorax: \\ Freie Flüssigkeit - und nun?
}

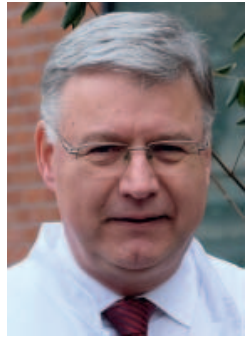

Dr. med. Dr. h. c. Jörg H. Simanowski
Correspondence

Dr. med. Dr. h.c. Jörg H. Simanowski

Medizinische Hochschule Hannover, AGVA-Chirurgie und leitender Arzt der Interdisziplinären Zentralen Notaufnahme des Klinikums Nordstadt des Klinikums der Region Hannover, Haltenhoffstraße 41, 30167 Hannover

Simanowski.Joerg@mh-hannover.de

Bibliography

DOI https://doi.org/10.1055/a-0942-3686

Published online: 2019

Ultraschall in Med 2019; 40: 552-559

(c) Georg Thieme Verlag KG, Stuttgart · New York

ISSN 0172-4614
Next to clinical evaluation, free fluid is a critical determinant of treatment urgency in the case of a consequence of trauma or an acute disease of the abdomen and chest.

Surgeons must perform exploratory laparotomy/scoping for every acute abdomen and every trauma with free fluid unless it can be proven that the disease/consequence of an injury can be treated conservatively. In addition to symptoms, the amount of free fluid detected on ultrasound can serve as an indication for exploratory laparotomy in cases of doubt. In the case of every relevant intraabdominal and, to a lesser extent, intrathoracic disease requiring immediate treatment, free fluid can be detected on ultrasound with very high sensitivity and specificity. The reverse conclusion can also be made: no free fluid, no disease requiring immediate treatment. In contrast, direct detection of the underlying disease on ultrasound and radiology has significantly lower rates of sensitivity.

The CME article published in this journal and entitled Neue Perspektiven für das moderne Trauma-Management-Lehren aus 25 Jahren FAST und 15 Jahren E-FAST by the authors ... [...] provides a summary of the current literature regarding the diagnosis and clinical significance of free fluid caused by trauma. The authors rightly conclude their article with the question "what does the detection of free fluid mean for the patient, physician, hospital, and society based on current knowledge?". In short: Free fluid - what now? Quick differentiation of free fluid is needed in all acute abdominal and thoracic diseases so that the following, in contrast to the cited article, relates not only to blunt trauma but also to the acute abdomen of unclear etiology.

The objective of this editorial is to close the diagnostic gap between the presence/detection of free fluid and the cause in order to avoid delays for further diagnostic imaging and/or to allow immediate targeted rather than exploratory treatment. A further goal is to use abbreviated algorithms to reduce radiation exposure, decrease worsening of the general condition, accelerate treatment, and significantly increase treatment quality.

It is helpful to answer the following five questions for acute diseases and trauma:

What: Type of fluid

How much: Amount of fluid

Where: Location of the fluid

How: can the fluid be accessed

From where: Origin of the fluid

To make a final clinical diagnosis, the ultrasound finding should always describe the amount, location, type, and, if possible, also the (presumed) cause of the free fluid. A previously (!) performed clinical examination (anamnesis, inspection, palpation, auscultation, if applicable) and the resulting suspected/working diagnosis are absolutely necessary and must be correlated with a focused medical question regarding the following ultrasound examination.

\section{Definition of free fluid and point at which it becomes pathological}

$50-75 \mathrm{ml}$ of intraperitoneal fluid is considered physiological [2]. It allows the organs to glide against one another as part of the elasticity of the body. Using conventional ultrasound techniques, "free fluid" can first be detected on ultrasound at 5-50 ml. The rule that 
"free fluid" is synonymous with pathological is outdated. But at what point should the amount and type of free fluid be classified as pathological and in particular at what point does this finding have immediate therapeutic consequences? Rough estimates of small amounts are performed using the volume formula with multiple spaces being added as applicable. Margins with a width of $1 \mathrm{~cm}$ correspond to $200 \mathrm{ml}$ in each space in an abdomen without adhesions [3], approximately 1 liter in all abdominal or hemithoracic segments with respect to an approximately normal-sized adult. The relativities remain the same in smaller/larger people.

\section{Where can free fluid be detected}

The thoracic cavity, the abdominal cavity including the omental bursa and the retroperitoneum are preformed compartments that are separated from one another in the embryonic phase. The abdominal cavity in particular has numerous recesses. Emergency patients usually arrive at the emergency room in a supine position. If there are no adhesion-related restrictions, gravity causes the free fluid to collect in the peritoneal cavity in the three most dorsal segments of the visceral cavities. According to the literature, these are the hepatorenal recess (Morison's pouch) in the right-lateral-dorsal position, the splenorenal recess [4] in the leftlateral-dorsal position, the pouch of Douglas in the middle caudal position in women, and the rectovesical pouch in men. Based on our own surgical experience and on ultrasound findings, we know that the hepatorenal recess on the right as cranioventral part of the subhepatic recess and the splenorenal recess on the left as cranioventral part of the left-dorsal recess in the upper abdomen are not the lowest points. All parts of the kidneys and the renalretroperitoneal coverings adjacent to the recess are further ventral. From the dislocation of the liver or spleen for trauma care, we know that because of gravity the blood runs into the dorsal spaces cranial thereto, the subhepatic recess or the dorsal, left subphrenic recess, and does not remain on the surface of the kidney. As a result of the weight of the liver and spleen pressing in a dorsal direction, these spaces are narrow. Fluid in the hepatorenal recess or the splenorenal recess indicates an overflow from the dorsal portion. Regarding the third lowest point in supine patients mentioned in the literature, we are going a step further and consider it the dynamically lowest point. When the patient is in a supine position, all infracolic fluid runs between the colic flexures into the small pelvis and from there, when a certain amount is exceeded, lateral-paracolic in a subhepatic and subphrenic direction. If free fluid is detected in the region of the peritoneal fold, which is attached to the rectum at greatly varying heights, in a prerectal location when the bladder is full, the fluid is from the physiological inflow region or it is fluid overflowing from the cranial abdominal cavity. When the patient is sitting or standing, gravity causes the fluid to drain from the abdominal cavity into the rectouterine pouch in women and the rectovesical pouch in men where the fluid then remains. These flow courses were already impressively outlined in 2009 by Levy et al. on the basis of intraabdominal tumor spread via physiological fluid [5]. Some of the recess terms, splenorenal recess, used in ultrasound and here are not included in the globally accepted nomenclature Nomina/

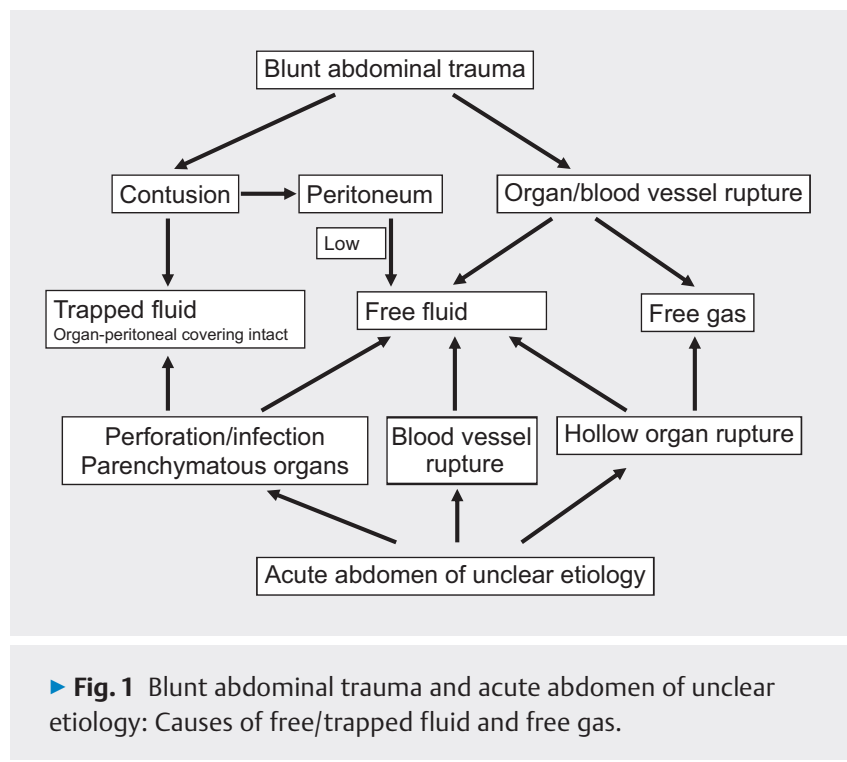

Terminologica anatomica (2nd edition, 2011) and are thus not known controversial according to anatomists. Therefore, we feel that it is useful for daily practice to label the location of free fluid according to the main locations in supine patients: Abdomen: $\mathrm{A} 1$ = right upper abdomen, $\mathrm{A} 2$ = left upper abdomen, $\mathrm{A} 3$ = lower abdomen; thorax: $\mathrm{T} 1$ = right thorax, $\mathrm{T} 2$ = left thorax; $\mathrm{B}=$ omental bursa; retroperitoneum: $\mathrm{R} 1=$ right retroperitoneal cavity, $\mathrm{R} 2$ = left retroperitoneal cavity, heart $=\mathrm{H}$.

\section{What: Type of fluid}

The type of fluid is more important than the total amount of fluid. It would be ideal if the type of fluid could be differentiated noninvasively with imaging of the fluid by measuring the density and corpuscular components and the most probable origin of the fluid could be determined based on location. This has been successfully achieved on CT in initial approaches for larger amounts of fluid and on (parametric) ultrasound for smaller amounts. However, the methods are not (yet) reliable enough. The criteria are the possible density of the fluid and internal corpuscular echoes. Limits, particularly in the daily routine, include the low sensitivity of low-quality devices as are often used in the emergency setting. A few millimeters are sufficient for differential diagnosis of the fluid. The acquired fluid should be held up to daylight or at least a bright white light. The visual finding provides key information (see $>$ Fig. 2). In the case of borderline findings, laboratory analysis is indicated. The following applies: A hemoglobin level that is close to a systemic value = relevant bleeding, leukocyte count $>1000 / / \mu \mathrm{l}=$ infection, $\alpha$-amylase: $>$ serum value $=$ affection of the pancreas, urea $>$ serum value $=$ leak in the urinary tract. If applicable, bacteriology and cytology samples should also be taken for subsequent classification. Where is it safe to puncture: In principle, anywhere, but ideally in the interstitial spaces near the surface. The bowel usually moves out of the way. If possible, do not puncture the colon (due to bacterial count). Never puncture the eye or the heart. 


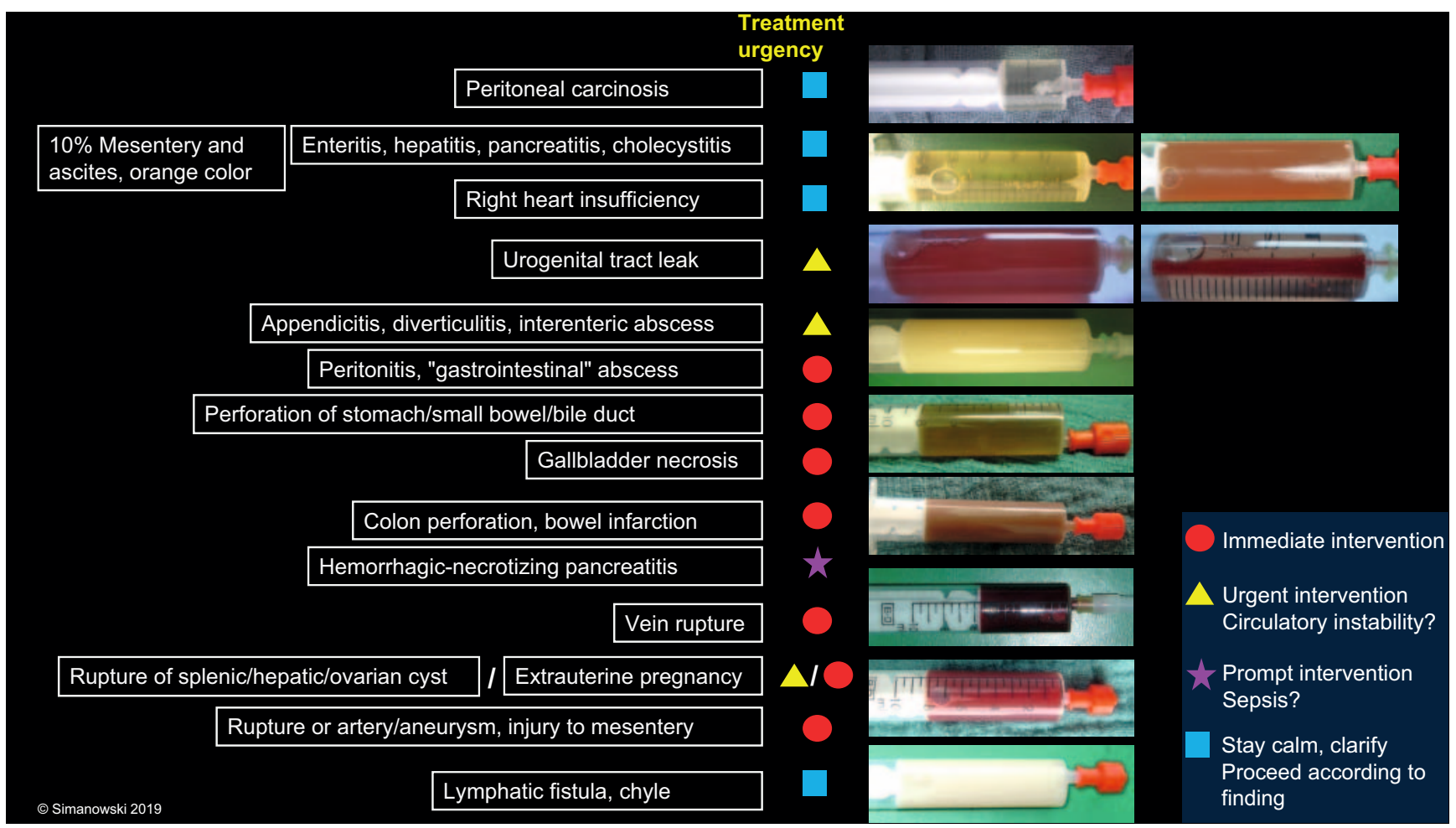

- Fig. 2 Blunt trauma and acute diseases of unclear etiology: Examples of the most common fluids collected from the abdominal cavity under ultrasound guidance in the emergency setting with prima-vista diagnoses and suggestions regarding the urgency of emergency treatment which is, however, always an individual decision on-site. All concrete information, at least the visual diagnosis of the fluid and the general clinical condition, must be summarized for the clinical decision under time pressure in the emergency situation. Using the proposed algorithm, the error rate can be significantly reduced and the introduction of correct treatment can be accelerated significantly.

\section{How: can the fluid be accessed}

With ultrasound as the absolute first-line imaging method, it is possible to detect free fluid with very high sensitivity or to rule it out with very high specificity. The direct detection of a consequence of trauma or of an acute disease can be significantly more time-consuming, difficult, or even impossible with ultrasound as well as other diagnostic imaging methods, particularly in the case of injuries to the gastrointestinal or urogenital tract. This additional time is often not available due to the progressive worsening of the patient's general condition and quality criteria. Targeted ultrasound-guided puncture to acquire free fluid material and visual diagnosis of the sample allow accurate diagnosis and treatment without a further delay. As a rule, puncture should be performed only by physicians using the shortest, least complicated access, usually directly under the parietal portion of the cavity. In basic terms: dark red = venous bleeding, light red = arterial bleeding, green = perforation of the upper gastrointestinal tract, brown = perforation of the lower gastrointestinal tract, beigecreamy $=$ pus, yellow $/$ orange-clear $=$ ascites, colorless-clear - primarily peritoneal carcinosis, white $=$ chyle, cloudy $=$ possible infec tion. Mixed types are also possible: e. g. urine-color-serous-bloodtinged: Bladder perforation ( $\bullet$ Fig. 2 ).

\section{From where: Origin of the fluid}

The borders can sometimes be blurred. Greenish or brownish fluid, arousing suspicion of a perforation of the upper or lower gastrointestinal tract, requires immediate surgical revision regardless of the amount of fluid. Red is an indication of active bleeding. However, a decision must be made in conjunction with the symptoms in this case. Immediate action is required in the case of circulatory instability/rapid increase in fluid. In the case of circulatory instability (possibly with administration of up to 2 blood transfusions), there is at least time to look for the cause. Particularly after trauma, larger amounts $>1$ liter can be tolerated in certain circumstances and particularly in children based on the individual's age and body under close intensive care monitoring because bleeding can occur spontaneously - also in the long term. Caution: long compensation with sudden decline. Clear, serous fluids initially eliminate the acute immediate need for treatment. These fluids have been present for a long time as an accessory symptom and are usually diagnosed "incidentally" as part of the critical disease. Cloudy fluids without direct detection of the cause should be differentiated at least via laboratory testing. In the case of acute symptoms, a laparoscopic/surgical or interventional approach should also be used. Pus in terms of a circumscribed abscess or a disease causing abscesses is treated interventionally, in a minimally invasive manner or in a cause-eliminating manner. If circumscribed free fluid is found in only one location, the cause should be sought in the surrounding area. Then the search 
should be expanded to include the described flow regions depending on the position of the body. Fluid located outside the organs that appears encapsulated can be an indication of an abscess, congenital or long-time acquired cystic changes, and rare anatomical variants. A direct view of the peritoneum occasionally reveals an inflammatory thickening or small nodules in the form of peritoneal metastases. In the case of free fluid above and below the diaphragm, a diaphragmatic rupture should always be considered (caution: Shear artifacts on the B-mode image can simulate a diaphragmatic rupture). Small quantities of free fluid after surgery are considered physiological for up to 10-14 days. Fluid in the retroperitoneum tends to be located in the renal capsule (inflammation, trauma, rupture of the calyx of the renal pelvis), perirenal and along the iliopsoas muscle (psoas abscess, psoas hematoma) and can often be classified clinically-anamnestically without diagnostic puncture. Abscesses should be drained ideally under ultrasound guidance. Fluid in the omental bursa with corresponding symptoms should be clarified ideally with puncture guidance (perforation of the rear abdominal wall) and drained if necessary (pancreatic abscesses, necrosis).

\section{Clinical evaluation of free fluid}

- Symptoms are always (?) the leading indicator... regardless of the fluid

- Ultrasound and ultrasound-guided fluid collection can provide quick and reliable diagnoses in emergency medicine. Further diagnostic imaging is often no longer necessary (saves resources).

- When the cause of free fluid is not immediately detected on ultrasound at our hospital, the free fluid is automatically collected in a targeted manner under ultrasound guidance taking into account any risks in the case of clinically relevant trauma as well as a highly acute abdomen. In our experience, the visual diagnosis of the fluid has always coincided with the surgical finding.

- Many different diseases have almost the same clinical symptoms. Targeted ultrasound-guided fluid collection can facilitate differentiation and faster decision-making.

- Knowledge of the location of the free fluid and the intraabdominal drainage pathways can result in faster determination of the cause.

- Medicine is always changing and ultrasound can effectively support this process with sophisticated diagnostics.

- Ultrasound is an effective method for follow-up examinations.

- However, in our opinion, new standard slices in eFAST plus are unnecessary due to the described algorithms. Transducers with a broad acoustic window record all relevant areas of the chest and abdomen with respect to fluid related to trauma.

\section{Stumpfes Trauma und akute Erkrankungen des Abdomens und Thorax: Freie Flüssigkeit - und nun?}

Freie Flüssigkeit ist neben der klinischen Einschätzung der entscheidende Marker für die Behandlungsdringlichkeit einer Traumafolge oder akuten Erkrankung des Abdomens und Thorax. 
Für Chirurgen gilt: Jedes akute Abdomen und jedes Trauma mit freier Flüssigkeit ist Probe zu laparotomieren/-skopieren, es sei denn, es gelingt der Nachweis einer konservativ behandelbaren Erkrankung/Verletzungsfolge. Insbesondere kann neben der Klinik im Zweifel die Menge von sonografisch nachgewiesener, freier Flüssigkeit als Indikation zur Probelaparotomie dienen. Bei jeder relevanten, sofort therapiepflichtigen, intraabdominellen und mit Abstrichen - thorakalen Erkrankung gelingt der sonografische Nachweis freier Flüssigkeit mit sehr hoher Sensitivität und Spezifität. Erlaubt ist der Umkehrschluss: Keine freie Flüssigkeit, keine unmittelbar behandelbare Erkrankung. Der direkte Nachweis der ursächlichen Erkrankung ist dagegen sonografisch wie auch radiologisch mit deutlich niedrigeren Sensitivitätsraten behaftet.

Der in diesem Heft erschienene CME-Artikel Neue Perspektiven für das moderne Trauma-Management - Lehren aus 25 Jahren FAST und 15 Jahren E-FAST der Autoren ... [...] fasst den aktuellen Welt-Literaturstand zur Diagnostik und klinischen Wertigkeit der traumatisch verursachten freien Flüssigkeit zusammen. Abschließend stellen die Autoren aber auch zu Recht die Frage, was nach den bisherigen Erkenntnissen das Erkennen freier Flüssigkeit dem Patienten, dem Arzt, der Klinik und der Gesellschaft bringt. Überspitzt zusammengefasst: Freie Flüssigkeit - und nun? Die Notwendigkeit zum raschen Differenzieren der freien Flüssigkeit gilt für alle akuten abdominellen und thorakalen Erkrankungen, sodass sich das Folgende im Gegensatz zu dem zitierten Artikel nicht nur auf das stumpfe Trauma, sondern auch auf das akute, unklare Abdomen bezieht.

Mit diesem Editorial soll die diagnostische Lücke zwischen dem Vorhandensein und dem Erkennen der freien Flüssigkeit und ihrer Ursache geschlossen werden, sodass weitere bildgebende Diagnostik nicht verzögert und/oder nicht explorativ eingesetzt wird, sondern sofort gezielt behandelt werden kann. Ziel ist auch, durch verkürzte Algorithmen Strahlenbelastung zu sparen, die Verschlechterung des Allgemeinzustands zu reduzieren, die Behandlung zu beschleunigen und damit die Behandlungsqualität entscheidend zu steigern.

Die Beantwortung folgender 5 „W“ für akute Erkrankungen und Traumata sind dazu zielführend:

\section{Was: Art der Flüssigkeit?}

Wieviel: Menge der Flüssigkeit?

Wo: Lokalisation der Flüssigkeit?

Wie: komme ich an die freie Flüssigkeit?

Woher: Ursprungsort der Flüssigkeit?

Vor einer endgültigen klinischen Diagnose sollte der sonografische Befund immer die Menge, die Lokalisation, die Art und falls möglich auch die (mutmaßliche) Ursache der freien Flüssigkeit beschreiben. Dabei ist der sonografische Befund immer mit einer zuvor (!) durchgeführten klinischen Untersuchung (Anamnese, Inspektion, Palpation, ggf. Auskultation) und daraus folgenden Verdachts-/Arbeitsdiagnose mit fokussierter, medizinischer Fragestellung an die Sonografie zu korrelieren.

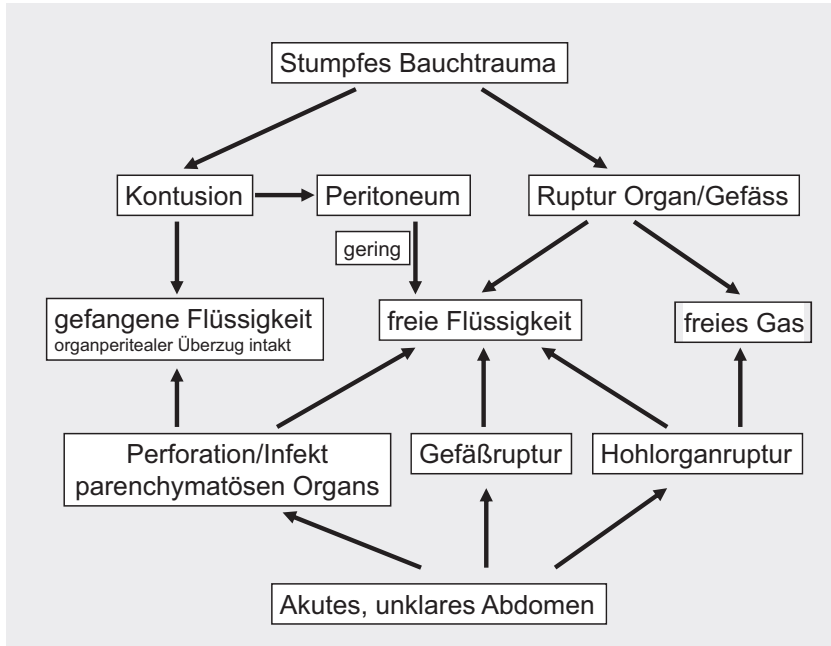

- Abb. 1 Stumpfes Abdomentrauma und akutes unklares Abdomen: Ursachen der freien/gefangenen Flüssigkeit und freien Luft.

\section{Definition der freien Flüssigkeit und ab welcher Menge gilt sie als pathologisch?}

Intraperitoneal sind 50-75 ml Flüssigkeit physiologisch [2], damit die Organe im Rahmen der Gesamtelastizität des Körpers gegeneinander gleiten können. Mit herkömmlicher Ultraschalltechnik gilt der sonografische Nachweis „freie Flüssigkeit“ erst ab 5-50 ml detektierbar. Die Regel „freie Flüssigkeit gleich pathologisch“ ist überholt. Doch ab wann sollte die Menge und auch die Art als pathologisch eingestuft werden und vor allem: Ab wann muss dieser Befund sofortige therapeutische Konsequenzen nach sich ziehen? Grobe Schätzungen für geringe Mengen erfolgen nach der Volumenformel, wobei mehrere Räume ggf. addiert werden sollten. Beim Abdomen ohne Adhäsionen entsprechen $1 \mathrm{~cm}$ breite Säume in den Winkeln je $200 \mathrm{ml}$ [3], in allen abdominellen oder hemi-thorakalen Anteilen ganz grob etwa 1 Liter bezogen auf einen etwa normal großen Erwachsenen, bei kleineren/größeren Menschen bleibt aber die Relativität gleich.

\section{Wo gelingt der Nachweis freier Flüssigkeit?}

Die thorakale Höhle, die abdominelle Höhle inklusive der Bursa omentalis und das Retroperitoneum sind präformierte Kompartimente, die embryonal voneinander getrennt sind. Besonders die Abdominalhöhle hat zahlreiche Recessus. Notfallpatienten erreichen die Notaufnahmen in aller Regel auf dem Rücken liegend. Liegen keine verwachsungsbedingten Einschränkungen vor, so sammelt sich in der Peritonealhöhle die freie Flüssigkeit der Schwerkraft folgend in den 3 am weitesten dorsal gelegenen Abschnitten der Körperhöhlen: Diese seien laut Literatur rechtslatero-dorsal der Recessus hepatorenalis (Morision-Pouch), linkslatero-dorsal der Recessus splenorenalis (Koller-Pouch [4]) und mittig-kaudal der Douglas-Raum bei der Frau und die Excavatio retrovesicale beim Mann. Aus eigener operativer Erfahrung und sonografischen Befunden wissen wir, dass der Recessus hepatore- 
nalis rechts als cranio ventraler Teil des Recessus subhepaticus und der Recessus splenorenalis links als cranio ventraler Teil des links-dorsalen Recessus im Oberbauch nicht den tiefsten Stellen entsprechen. Alle Teile der Nieren respektive der nierenretroperitonealen Überzüge, die Recessus-begrenzend sind, liegen weiter ventral. Aus dem Hervorluxieren der Leber oder der Milz zur Traumaversorgung wissen wir, dass das Blut der Schwerkraft folgend in die kranial davon befindlichen dorsalen Räume, den Recessus subhepaticus bzw. dorsalen linken Recessus subphrenicus läuft und nicht auf der Nierenoberfläche verbleibt. Das nach dorsal drückende Gewicht der Leber und der Milz machen diese Räume schmal, findet man Flüssigkeit im Morrison- oder Koller-Pouch, so handelt es sich bereits um einen Mengenüberlauf aus dem dorsalen Anteil. Bezüglich der dritten in der Literatur erwähnten tiefsten Stelle bei auf dem Rücken liegenden Patienten gehen wir einen Schritt weiter und betrachten sie als dynamisch am tiefsten. Im Liegen läuft der Schwerkraft folgend sämtliche infrakolische Flüssigkeit zwischen den Kolonflexuren ins kleine Becken und von dort, wenn eine gewisse Menge überschritten wird, jeweils lateroparakolisch nach subhepatisch und -phrenisch. Findet man im Bereich der peritonealen Umschlagsfalte, die individuell sehr unterschiedlich hoch als Umschlagsfalte am Rektum angeheftet ist, prärektal bei möglichst voller Harnblase freie Flüssigkeit, so stammt sie aus dem physiologischen Zuflussgebiet oder es handelt sich um Flüssigkeit aus der kranialen Bauchhöhle bei sehr viel freier Flüssigkeit im Sinne eines Überlaufs von dort. Im Sitzen und Stehen läuft aus dem gesamten Bauchraum die Flüssigkeit der Schwerkraft folgend in die Excavatio rectouterina bei der Frau und retrovesicalis beim Mann und verbleibt dort. Diese Flussläufe sind bereits 2009 von Levy et al. anhand der intraabdominellen Tumorausbreitung mittels physiologischer Flüssigkeit eindrucksvoll skizziert worden [5]. In der weltweit konsentierten Nomenklatur Nomina/Terminologica anatomica (2. Auflage, 2011) sind ein Teil der in der Sonografie eingeführten RecessusBegriffe, Recessus splenorenalis und Koller-Pouch nicht aufgeführt und somit aus Sicht der Anatomen nicht bekannt und damit zumindest strittig. Daher sehen wir für den praktischen Alltag die Benennung der Lokalisation von freier Flüssigkeit nach den auf dem Rücken liegenden Haupt-Lokalisationen als eher sinnvoll an: Abdomen: $A 1$ = rechter Oberbauch, A2 = linker Oberbauch, A3 = Unterbauch; Thorax: T1 = rechter Thorax, T2 = linker Thorax; B = Bursa omentalis; Retroperitoneum: R1 = rechter Retroperitonealraum, R2 = linker Retroperitonealraum; Herz = H.

\section{Was: Art der Flüssigkeit}

Wichtiger als die Gesamtmenge an Flüssigkeit ist die Art der Flüssigkeit. Ideal wäre, wenn man mit einer Bildgebung aus der Flüssigkeit durch Messung von Dichte und korpuskulären Bestandteilen die Art der Flüssigkeit und u. U. durch die Lokalisation den wahrscheinlichsten Ursprungsort der Flüssigkeit nichtinvasiv differenzieren könnte. Dieses gelingt im CT in ersten Ansätzen für größere Flüssigkeitsmengen, im (parametrischen) Ultraschall auch in kleineren Mengen, alles aber (noch) nicht zuverlässig genug. Kriterien sind die mögliche Dichte der Flüssigkeit und korpuskuläre Binnenechos. Eine Grenze, besonders in der täglichen Rou- tine, ist z. B. eine niedrige Sensitivität bei Geräten mit minderer Qualität, wie sie häufig in der Notfalldiagnostik eingesetzt werden. Zur Artdiagnose der Flüssigkeit reichen wenige Milliliter aus. Die gewonnene Flüssigkeit sollte gegen das Tageslicht oder zumindest eine helle, weiße Lichtquelle gehalten werden. Der optische Befund ist beweisend ( $\triangleright$ Abb. 2). Bei grenzwertigen Befunden ist eine Laborbestimmung indiziert. Es gilt: Hämoglobin je näher am systemischen Wert = relevante Blutung, Leukozytenzahl $>1000 / \mu \mathrm{l}=$ Infekt, $\alpha$-Amylase $>$ Serumwert $=$ Pankreasaffektion, Harnstoff $>$ Serumwert = Leckage des Harntrakts. Auch die Abnahme einer Bakteriologie und Zytologie für die spätere Einordnung sollte ggf. gleich mit vorgenommen werden. Und wo darf man hineinstechen? Im Prinzip überall, man sollte aber möglichst in oberflächennahen Zwischenräumen bleiben; der Darm weicht meist aus, wenn möglich nicht durch das Kolon stechen (wegen der Keimzahl), nie ins Auge und nicht ins Herz.

\section{Wie: komme ich an die freie Flüssigkeit?}

Mit der Sonografie als absoluter First-line-Bildgebung gelingt der Nachweis freier Flüssigkeit mit sehr hoher Sensitivität bzw. der Ausschluss mit sehr hoher Spezifität. Der direkte Nachweis der Traumafolge oder der akuten Erkrankung kann mit der Sonografie, wie auch mit anderer bildgebender Diagnostik, deutlich langwieriger, schwieriger oder sogar unmöglich sein, besonders bei Verletzungen des Gastrointestinal- oder Urogenitaltrakts. Diese zusätzliche Zeit steht häufig wegen der fortschreitenden Reduktion des Allgemeinzustands und Qualitätskriterien nicht zur Verfügung. Die Sonografie-gezielte Punktion zur Gewinnung von freiem Flüssigkeitsmaterial und die Sichtdiagnose ermöglichen ohne weitere Verzögerung die zielgenaue Diagnose und Therapie. Sie sollte grundsätzlich nur durch Ärzte und dort erfolgen, wo der kürzeste komplikationsarme Weg besteht, meist direkt unter dem parietalen Anteil einer Höhle. Dabei gilt ganz grob und vereinfacht: dunkelrot = venöse Blutung, hellrot = arterielle Blutung, grün = Perforation oberer Gastrointestinaltrakt, braun = Perforation unterer Gastrointestinaltrakt, beige-rahmig = Eiter, gelb-/ orange-klar = Aszites, farblos-klar = V. a. Peritonealkarzinose, weiß = Chylus, trüb = Infekt möglich. Mischformen sind möglich: z. B. Urin-farben-serös-blutig-tingiert: Harnblasenperforation ( $\triangleright$ Abb. 2).

\section{Woher: Ursprungsort der Flüssigkeit}

Die Übergänge können manchmal fließend sein. Grün- oder bräunliche Flüssigkeit, also der Verdacht auf eine Perforation des oberen oder unteren Gastrointestinaltrakts, benötigt unabhängig von der Menge eine sofortige operative Revision. Rot ist Ausdruck für eine aktive Blutung. Hier muss jedoch gemeinsam mit der Klinik entschieden werden. Bei Kreislaufinstabilität/rascher Flüssigkeitszunahme muss sofort adäquat gehandelt werden. Bei Kreislaufstabilität (ggf. unter Gabe von bis zu 2 Blutkonserven) hat man zumindest Zeit nach der eigentlichen Ursache zu fahnden. Besonders nach Traumata können größere Mengen > 1 Liter u. U. und besonders bei Kindern alters- und körperindividuelle Mengen unter strenger intensivmedizinischer Beobachtung toleriert wer- 


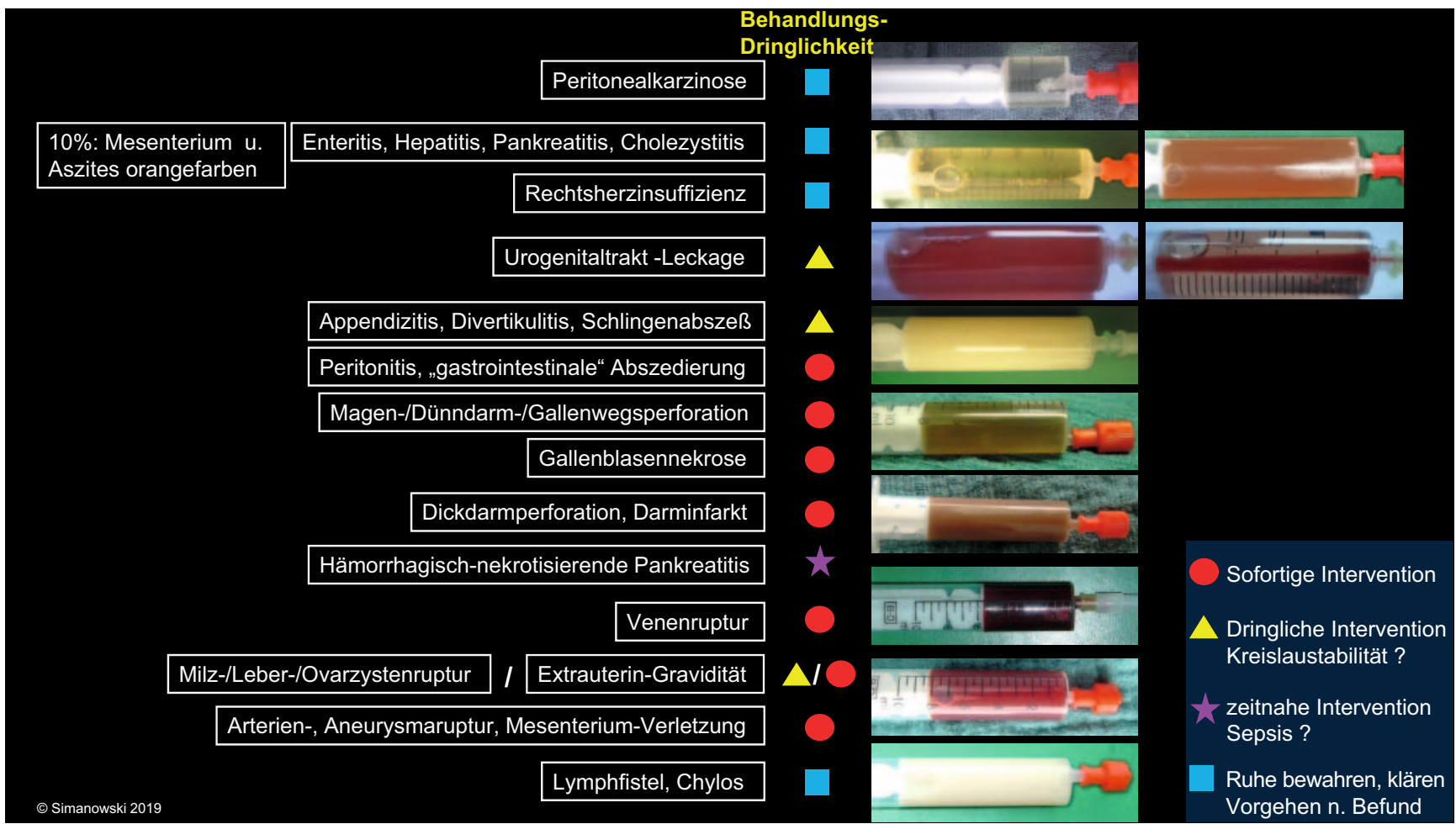

- Abb.2 Stumpfes Trauma und akute unklare Erkrankungen: Beispiele der häufigsten, im Notfall Sonografie-gezielt aus dem Bauchraum gewonnenen Flüssigkeiten mit prima-vista-Diagnosen und Vorschläge zur Notfall-Behandlungsdringlichkeit, die jedoch immer eine Individualentscheidung vor Ort ist. Alle greifbaren Informationen, mindestens die Blickdiagnose der Flüssigkeit und der klinische Allgemeinzustand sind zur klinischen Entscheidung bei zeitlichem Druck in der Notsituation zusammenzufassen. Mit dem vorgeschlagenen Algorithmus kann die Rate an Irrtümern erheblich reduziert und die Einleitung einer korrekten Behandlung wesentlich beschleunigt werden.

den, weil nicht selten Blutungen spontan zum Stehen kommen auch auf lange Sicht. Cave: lange Kompensation mit plötzlichem Abfall. Klare, seröse Flüssigkeiten nehmen aus allem erst einmal die akute, unmittelbare Behandlungsnotwendigkeit heraus. Sie sind als Begleiterscheinung länger bestehend und werden meist „zufällig“ im Rahmen der Notfallerkrankung mitdiagnostiziert. Trübe Flüssigkeiten ohne direkten Ursachennachweis sollten zumindest laborchemisch differenziert werden, bei akuter Klinik ggf. auch laparoskopisch/operativ oder interventionell angegangen werden. Eiter im Sinne eines umschriebenen Abszesses oder einer abszedierenden Erkrankung werden interventionell, minimalinvasiv bzw. ursachenbeseitigend therapiert. Findet man umschriebene freie Flüssigkeit in nur 1 Lokalisation, so sollte man in der Nähe nach der Ursache suchen, als Nächstes erweitert in den geschilderten Zuflussgebieten je nach Körperlage. Außerhalb von Organen befindliche Flüssigkeit, die gekapselt erscheint, kann ein Hinweis für einen Abszess, angeborene oder bereits seit längerem erworbene zystische Veränderungen und seltenen anatomischen Varianten sein. Der direkte Blick auf das Peritoneum offenbart gelegentlich eine entzündliche Verdickung oder kleine Knötchen im Sinne einer Peritonealmetastasierung. Freie Flüssigkeit oberhalb und unterhalb des Zwerchfells sollte auch immer an eine Ruptur des Zwerchfells denken lassen (Cave: Scherartefakte im B-Bild können eine Zwerchfellruptur vortäuschen). Freie Flüssigkeit nach Operationen gilt in kleinen Mengen bis 10-14 Tage postoperativ als physiologisch. Flüssigkeit im Retroperitoneum findet sich am ehesten in der Nierenkapsel (Entzündung, Trauma, Nierenbeckenkelchruptur), perirenal und entlang des M. ileopsoas (Psoasabszess, -hämatom) und kann oft klinisch-anamnestisch ohne diagnostische Punktion eingeordnet werden. Abszesse sollten möglichst Sonografie-geleitet drainiert werden, Flüssigkeit in der Bursa omentalis sollte bei entsprechender Klinik möglichst mit apparativer Punktionsführung abgeklärt (Hinterwand-Magenperforation) und ggf. drainagetherapiert werden (Pankreasabszesse, -nekrosen).

\section{Klinische Wertung zur freien Flüssigkeit}

- Klinik ist immer (?) führend ... - unabhängig von der Flüssigkeit.

- Die Sonografie und die -geleitete Flüssigkeitsgewinnung können in der Notfallmedizin rasch und zuverlässig Diagnosen erkennen; eine weitere bildgebende Diagnostik ist dann häufig nicht mehr notwendig (spart Ressourcen).

- Wenn in unserer Klinik die Ursache der freien Flüssigkeit nicht sofort mit der Sonografie erkannt wird, so wird beim klinisch relevanten Trauma wie auch hoch-akuten Abdomen reflexartig die freie Flüssigkeit Sonografie-gezielt gewonnen, ggf. unter Abwägung der Risiken. Wir haben nie erlebt, dass die Blickdiagnose aus der Flüssigkeit nicht mit dem operativen Befund übereingestimmt hat. 
- Es gibt viele unterschiedliche Erkrankungen, die fast die gleiche klinische Symptomatik haben. Hier kann die Sonografie-gezielte Flüssigkeitsgewinnung zur Differenzierung und schnelleren Entscheidungsfindung beitragen.

- Die Lokalisation der freien Flüssigkeit und das Wissen der intraabdominellen Drainagewege kann schneller zum Auffinden der Ursache führen.

- Medizin wandelt sich - die Sonografie kann mit einer differenzierten Diagnostik diesen Prozess sehr gut begleiten.

- Die Sonografie kann sehr gut zur Verlaufsbeobachtung eingesetzt werden.

- Neue Standard-Schnitte im Rahmen der E-FAST plus halten wir aufgrund der dargelegten Algorithmen eher für entbehrlich. Schallköpfe mit breitem Schallfenster erfassen alle traumaflüssigkeitsrelevanten Areale des Thorax und Abdomens.

\section{Conflict of Interest}

The author declares that he has received lecture fees from Mylan Healthcare $\mathrm{GmbH}$.

\section{References}

[1] CME-Artikel Neue Perspektiven für das moderne Trauma-ManagementLehren aus 25 Jahren FAST und 15 Jahren E-FAST.

[2] Walied Abdulla: Interdisziplinäre Intensivmedizin. München u. a.: Urban \& Fischer; 1999. ISBN: 3-437-41410-0486

[3] Röthlin M, Bouillon B, Klotter HJ (HG) Checkliste Sonografie für Chirurgen in der Reihe Checklisten der aktuellen Medizin, F. Largiadèr, O. Wicki, A. Sturm (HG). Stuttgart, New York: Thieme-Verlag. 1991. Stumpfes Bauch- und Thoraxtrauma, S. 148

[4] Hölscher A, Bäumler D, Bernhardt J. Transkutane Sonografie: Systembezogene, organübergreifende Untersuchung und sonografische Leitbefunde. In: Weiser HF, Birth M, (HG) Viszeralchirurgische Sonografie. Berlin, Heidelberg, New York: Springer Verlag ISBN: 3-540-63948-9

[5] Levy AD, Shaw JC, Sobin LH. Secondary Tumors and Tumorlike Lesions of the Peritoneal Cavity: Imaging Features with Pathologic Correlation. RadioGraphics 2009; 29: 347-373 